\title{
The Design and Synthesis of Biologically Active Organophosphorus Compounds - The Role of a Central Research Laboratory
}

\author{
Roger G. Hall*
}

\section{Dedicated to Prof. Dr. Daniel Belluš on the occasion of his 70th birthday}

\begin{abstract}
The properties and benefits offered by incorporating phosphorus into molecules are varied and numerous as shown by the many divisional research programs within Ciba-Geigy in the early eighties. This paper describes how a Central Research Group developed new materials in organophosphorous chemistry and identified new leads for life science applications.
\end{abstract}

Keywords: CGP 35348 - Crop protection · GABA-B · Life sciences · Organophosphorus regents

\section{Introduction}

In the early eighties the various divisional research groups of Ciba-Geigy were making significant investments in organophosphorus chemistry; this investment reflects the enormous variety of chemistry possible, and breadth of applications offered by incorporating phosphorus into molecules. In the technical divisions, the metal-chelating properties of phosphorus led to products such as Belcor 575, $\left.{ }^{1]}\right]$ which is still used today as a water-treatment chemical (Fig. 1). The ability of phosphorus to act as a flame retardant is exploited through products such as Pyrovatex ${ }^{[2]}$ or the Reofos triarylphosphate range of products. In addition, the ease by which acyl phosphine oxides undergo photolytic cleavage to generate radicals led to a range of photoinitiators $^{[3]}$ for the polymer industry.

In the field of crop protection, the search for new organophosphate insecticides was essentially over by this time; however, when the herbicidal activity of Glyphosate (Fig. 2) became evident ${ }^{[4]}$ the race was on to find a second such product. Within the pharmaceutical division, probably the largest research effort at that time
${ }^{*}$ Correspondence: R. G. Hall

Syngenta Crop Protection Münchwilen AG Research Chemistry

WST-810.3.18

$\mathrm{CH}-4332$ Stein

Tel.: + 41613233210

Fax: + 41613238726

E-mail: roger_g.hall@syngenta.com

\begin{tabular}{|ccc|} 
Belcor 575 & Pyrovatex & Reofos \\
\hline
\end{tabular}

Fig. 1.

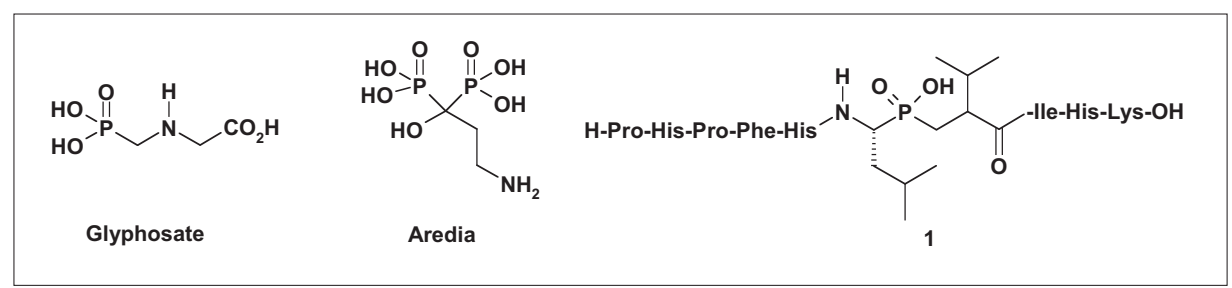

Fig. 2.

was in the use of bis-phosphonic acids as calcium chelators, leading to products such as Aredia ${ }^{[5]}$ to treat bone disorders. Only sporadic efforts were being made to exploit the ability of phosphorus to mimic the tetrahedral transition state involved in peptide bond cleavage, and thus identify new, specific enzyme inhibitors. One project targeted the enzyme Renin, and molecules such as 1 were prepared, where the leucine-valine amide linkage was replaced by a phosphinic acid, leading to potent inhibitors $\left(\mathrm{IC}_{50}=75 \mathrm{nM}\right) .{ }^{[6]}$

And thus, with so much research already being performed throughout the company, how was a Central Research Laboratory able to complement those divisional research programs and contribute in the area of organophosphorus chemistry?

A strong influence which helped shape the role of this Central Research group in Manchester, UK was the increasing number of organophosphorus compounds being isolated from natural sources, which contained one or more carbon-phosphorus bonds. ${ }^{[7]}$ More importantly, many of these compounds exhibited some interesting biological properties, such as antibiotic activity. Another important factor for the group at that time was the lack of availability of key building blocks which would allow more general and flexible synthetic approaches to highly functionalized organophosphorus compounds. It is here that our story begins.

\section{Results and Discussion}

\section{$\mathrm{H}_{3} \mathrm{PO}_{2}$ Building Blocks}

An important event in this story was a poster presented ${ }^{[8]}$ at the IUPAC conference on Organophosphorus Chemistry in Durham, North Carolina in 1979. Here, M. J. Gallagher described the reaction of $\mathrm{H}_{3} \mathrm{PO}_{2}$ with orthoesters in some sugar-inspired chemistry; Dingwall and colleagues realised that the $\mathrm{P}-\mathrm{H}$ function could be protected as an acetal group, and later removed upon acid hydrolysis. This concept was taken up by the Central Research group and over the next few years a com- 


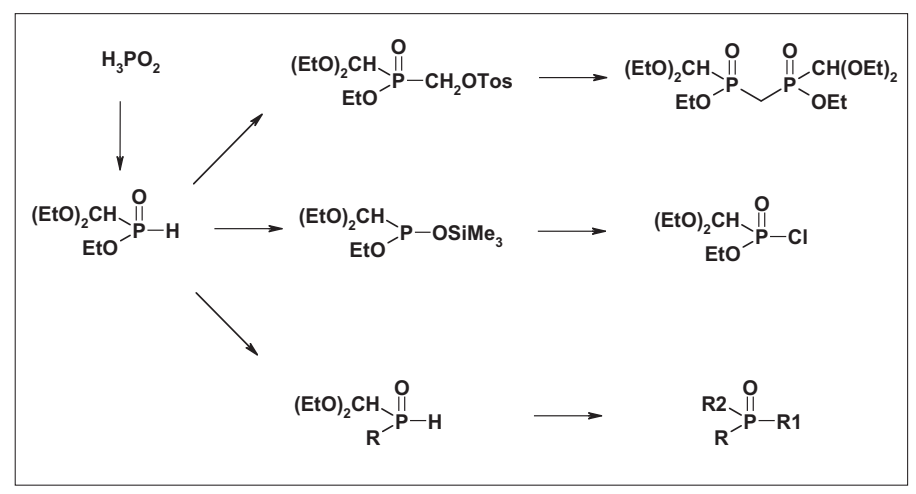

Scheme 1.

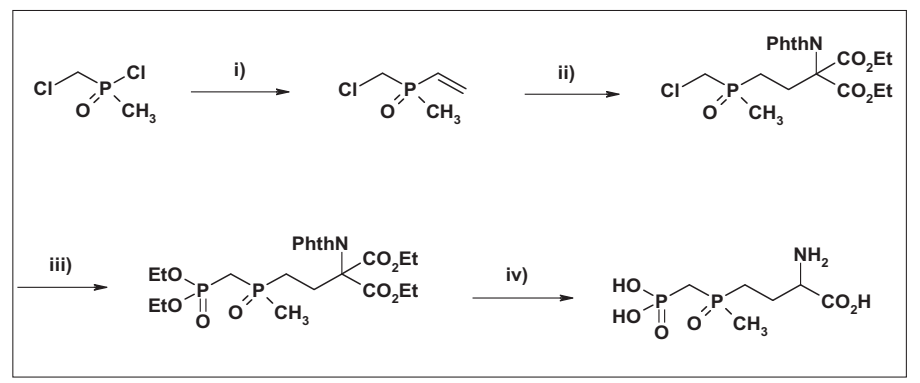

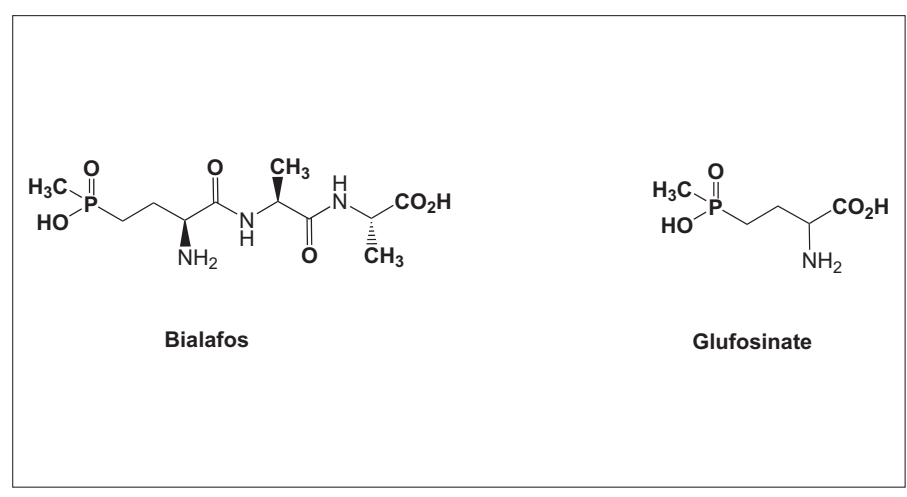

Fig. 3.

Scheme 2. Reaction conditions: i) vinyl magnesium bromide, $\mathrm{THF},-50{ }^{\circ} \mathrm{C}, 35 \%$; ii) $\mathrm{N}$-phthalimidomalonate, $\mathrm{NaOEt}$, $\mathrm{EtOH}, 82 \%$; iii) neat triethylphosphite, $100{ }^{\circ} \mathrm{C}, 55 \%$; iv) conc. $\mathrm{HCl}$, heat, then propylene oxide, $59 \%$ plete range of reagents ${ }^{[9]}$ were prepared, a selection of which are shown in Scheme 1.

The utility of these building blocks is based on a protection - functional group transformation - deprotection strategy, and proved to be highly successful in the synthesis of new (thio)-phosphorus acids of biological interest. The approach was extended to include other protecting groups which could be removed under milder conditions, ${ }^{[10]}$ and also to the synthesis of functional phosphine oxides.[11]

With these building blocks in hand, in some cases prepared in kilogram quantities $^{[12]}$ the search for new leads could be taken up in earnest with, in the first instance a focus on life sciences.

The rational design of bio-actives containing phosphorus can be divided into three main approaches, a) transition state or high-energy intermediate analogues, b) bio-isosteric replacement of carboxylic acids, and c) phosphonate mimics of phosphates.

\section{Transition State Analogues}

In the field of crop protection, a fermentation product Bialophos (Fig. 3) was introduced onto the market in $1984,{ }^{[13]}$ as a non-selective herbicide. Two years later, the amino acid Glufosinate ${ }^{[14]}$ was introduced; these products act by inhibiting the enzyme glutamine synthetase blocking the primary source of nitrogen uptake in plants. It has been shown that the phosphinic acid is itself phosphorylated, and that the methyl group sits over the enzyme pocket which binds the ammonia.
We had a small program directed towards identifying new inhibitors of this enzyme, one example of which is shown in Scheme 2.

Unfortunately this compound proved to be inactive in vivo and did not show any enzyme inhibition in a semi-purified enzyme assay. Inhibition values for related analogues are shown in Table 1.

\section{Bioisosteric Replacement of Carboxylic Acids}

A significant amount of research has been published in this area, with the vast majority focused on preparing phosphonic acid analogues of carboxylic acids. As phosphonic acids are present as dianions at physiological $\mathrm{pH}$, we believed that phosphinic-H-acids would be closer analogues, where the additional ligand compared to a carboxylic acid is a proton. A number of such P-H phosphinic acids have been isolated from natural sources ${ }^{[15]}$ and have been shown to function as biosynthetic intermediates. Indeed, colleagues then at Ciba-Geigy prepared analogues of 20 $\alpha$-amino acids, and found nine to display interesting biological activity, suggesting that this approach held potential.

Ultimately, it was in the area of $\gamma$-amino phosphinic acids that the breakthrough came. The parent compound, 3-aminopropylphosphinic acid was prepared ${ }^{[16]}$ using a building block described above. This compound binds selectively to the GABA$\mathrm{B}$ receptor with an affinity $\left(1 \times 10^{-9} \mathrm{M}\right)$ higher than that of the natural inhibitory
Table 1. Inhibition of glutamine synthetase by Glufosinate and related compounds. Inhibtion was measured at a concentration of 12 m.mol/litre using photometric measurements. Compounds marked * exist in a $\mathrm{pH}$-dependent equilibrium with the pyrroline as seen by NMR spectroscopy

\begin{tabular}{|c|c|c|}
\hline $\begin{array}{l}\text { Com- } \\
\text { pound }\end{array}$ & Structure & $\begin{array}{l}\text { Inhibi- } \\
\text { tion [\%] }\end{array}$ \\
\hline $\begin{array}{l}\text { Glufos- } \\
\text { inate }\end{array}$ & & 100 \\
\hline 2 & & 85 \\
\hline 3 & & 66 \\
\hline 4 & & 66 \\
\hline $5^{\star}$ & & 45 \\
\hline $6^{*}$ & & Inactive \\
\hline 7 & & Inactive \\
\hline
\end{tabular}

neurotransmitter. ${ }^{[17]}$ Because of this high potency and selectivity, tritiated CGP 27492 (Fig. 4) has become the radioligand of choice ${ }^{[18]}$ for such receptor-binding studies. Introduction of a para-chlorophenyl group in the 2-position resulted in a compound CGP 35832 which displayed a remarkably similar biological profile to the marketed muscle relaxant Baclofen.

3-Aminopropyl phosphinic-H-acids were shown to be selective GABA-B agonists, and at this stage of the project GABA-B antagonists were unknown. Increasing the size of the extra ligand from a proton to a methyl group, $\gamma$-aminopropylmethyl-phosphinic acids were obtained showing again potent agonist activity.

However, C(2) homologues and higher proved to be GABA-B antagonists. [19] CGP 35348 administered either $i v$ or ip could 

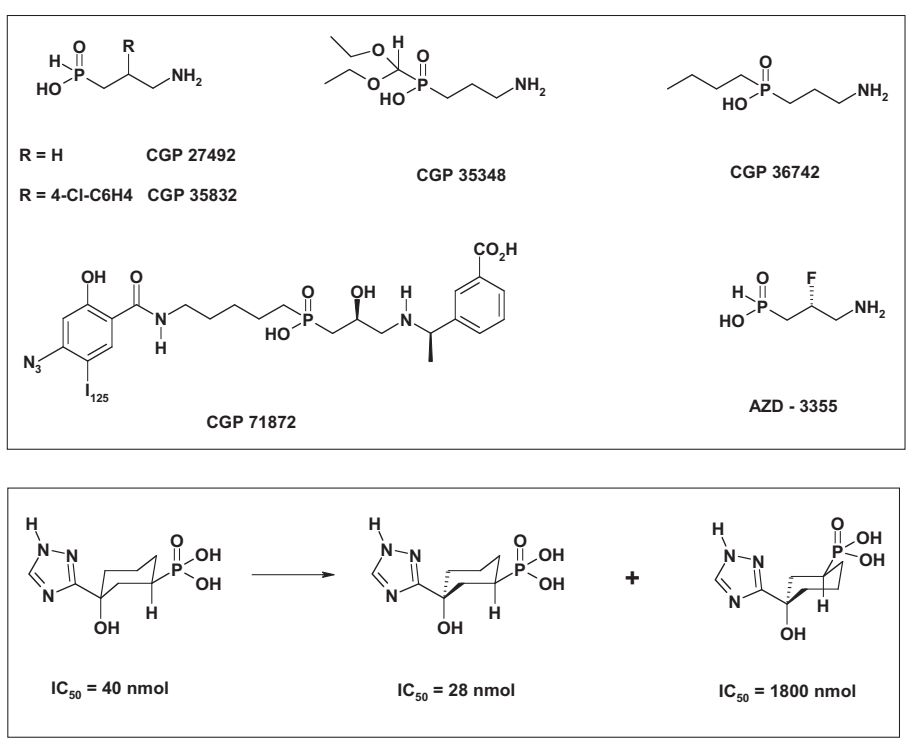

Scheme 3. Nanomolar levels of IGPD inhibition resulting from enantiomeric separation.

block the effect of Baclofen and thus was able to penetrate the blood brain barrier; CGP 36742 was the first GABA-B antagonist to be active upon oral administration. Such compounds offered new therapeutic opportunities, and CGP 36742 was tested in clinical trials ${ }^{[20]}$ for the treatment of Alzheimers disease. In addition, these new antagonists have given biologists new tools with which to study receptor-mediated effects in the central nervous system, as can be judged by the more than 500 references which cite CGP 35348. [21]

Further optimization of these molecules then led to extremely potent GABAB antagonists such as CGP 71872 used as ligands in the expression cloning ${ }^{[22]}$ of GABA-B receptors, giving for the first time tools to study receptor heterogeneity. More recently the GABA-B story has taken a new direction; researchers at AstraZeneca have discovered GABA-B agonists which show benefits in the treatment of gastro-intestinal diseases. ${ }^{[23]}$ Interestingly, in this area the aminopropylphosphinic-Hacids offer a better tolerability than other phosphorus acids, and AZD-3355 (lesogaberan) is currently in Phase 2 clinical trials $^{[24]}$ for the treatment of gastroesophagel reflux disease. In yet another application, GABA-B antagonists have also been investigated to treat eye disorders. [25]

\section{Phosphonic Acid Mimics of Phosphates}

A significant amount of research has been published in this area, with the goal to find novel enzyme inhibitors. In the field of crop protection however, relatively little has been explored; one opportunity was identified in amino acid biosynthesis, specifically looking to block histidine biosynthesis in the search for new herbicides. The enzymatic step targeted for inhibi- tion was Imidazole Glycerol Phosphate Dehydratase (IGPD) and molecules were designed where the imidazole ring was replaced by a triazole (either $\mathrm{C}$ - or $\mathrm{N}$ - linked) and chain lengths were varied linking the heterocycle and phosphonic acid groups.[26] Most of the research on this project was carried out at the International Research Laboratories in Japan.

As knowledge on the structure-activity relationship grew, restricted conformations were prepared with cyclohexane derivatives showing nanomolar levels of enzyme inhibition (Scheme 3). In this series, chirality was also found to be important with the two enantiomers being separated by chiral chromatography and showing markedly different levels of enzyme inhibition.

Attempts to prepare cyclobutane derivatives were partially successful, where an isomerisation late in the synthesis occurred giving unexpectedly the unwanted cis-derivatives. ${ }^{[27]}$ While in vitro levels of activity could be successively improved, the herbicidal effects seen in the glasshouse remained at levels too weak for commercial applications, and so far a product has not resulted from this research. However, the crystal structure of this enzyme has now been published ${ }^{[28]}$ which could present new opportunities for the design of more potent compounds.

\section{Conclusions}

Incorporating phosphorus into a chemist's research program is probably not top of the priority list, and there are many reasons for this prejudice. In addition to this, we are now facing the problem of disappearance of supplies of natural phosphate ${ }^{[29]}$ which will undoubtedly lead to price increases for starting materials. However, with the correct design input, molecules with exciting biological properties can be prepared; from the examples noted above, phosphorus chemistry has made a significant contribution to the field of neuroscience research. The author is convinced that further, important discoveries in the life sciences will result by using such an approach.

Received: December 18, 2009

[1] B. Cook, N. Richardson, J. Tames, Ciba-Geigy PLC, EP 74336 - A1, 1983

[2] H. Nachbur, B. P. Stark, A. Maeder, Ciba, ZA 6804706, 1968

[3] W. Rutsch, K. Dietliker, R. G. Hall, Ciba-Geigy, EP 413657 - A1, 1991.

[4] E. G. Jaworski, J. Agri. Food. Chem. 1972, 20, 1195.

[5] O. L. Bijvoet, P. H. Reitsma, W. B. Frijlink, Lancet 1980, 1, 1416.

[6] M. C. Allen, W. Fuhrer, B. Tuck, R. Wade, J. M. Wood, J. Med. Chem. 1989, 32, 1652.

[7] H. Seto, T. Kuzuyama, Nat. Prod. Reports, 1999, 16, 589

[8] M. J. Gallagher, H. Honegger, Aus. J. Chem. 1980, 33, 287.

[9] J. G. Dingwall, J. Ehrenfreund, R. G. Hall, Tetrahedron 1989, 45, 3787.

[10] E. K. Baylis, Tetrahedron Lett. 1995, 36, 9385.

[11] R. G. Hall, P. Riebli, Synlett 1999, 10, 1633.

[12] P. S. Wardleworth, E. K. Baylis, Ciba-Geigy, EP 307362 - A2, 1989.

[13] S. Mase, Jap. Pest. Information 1984, 45, 27.

[14] S. Matsunaka, Farumashia 1985, 21, 1144.

[15] H. Seto, Com. Nat. Prod. Chem. 1999, 1, 865.

[16] J. G. Dingwall, J. Ehrenfreund, R. G. Hall, J. Jack, Phos. Sulf. 1987, 30, 571.

[17] J. Ong, N. L. Harisson, R. G. Hall, J. L. Barker, G. A. R. Johnston, D. I. B. Kerr, Brain Res. 1990, $526,138$.

[18] R. G. Hall, P. D. Kane, H. Bittiger, W. Froestl, J. Lab. Comp. \& Radiopharmaceuticals 1995, 36, 129.

[19] W. Froestl, S.J. Mickel, G. von Sprecher, P. J. Diel, R. G. Hall, L. Maier, D. Strub, V. Melillo, P. A. Baumann, R. Bernasconi, C. Gentsch, K. Hauser, J. Jaekel, G. Karlsson, K. Klebs, L. Maître, C. Marescaux, M. F. Pozza, M. Schmutz, M. W. Steinmann, H. van Riezen, A. Vassout, C. Mondadori, H.-R. Olpe, P. C. Waldmeier, H. Bittiger, J. Med. Chem. 1995, 38, 3313.

[20] W. Froestl, M. Gallagher, H. Jenkins, A. Madrid, T. Melcher, S. Teichman, C. G. Mondadori, R. Pearlman, Biochem. Pharmacol. 2004, 68, 1479.

[21] Sci Finder search 2009

[22] K. Kaupmann, K. Huggel, J. Heid, P. J. Flor, S. Bischoff, S. J. Mickel, G. McMaster, C. Angst, H. Bittiger, W. Froestl, B. Bettler, Nature 1997, $386,239$.

[23] T. Elebring, P. Guzzo, A. Holmen, T. Olsson, M. Swanson, S. Von Sverker, Astrazeneca, WO 2001042252 A1, 2001.

[24] J. A. Bredenoord, IDrugs 2009, 12, 576

[25] R. A. Stone, A. M. Laties, Trustees. Univ. Pennsylvania, USA, WO 9425018 A1, 1994.

[26] I. Mori, Y. Kimura, S. Matsunaga, T. Nakano, A. C. O'Sullivan, Ciba-Geigy, WO 9518811 A $1,1995$.

[27] R. D. Norcross, P. von Matt, H. C. Kolb, D. Bellus, Tetrahedron 1997, 53, 10289.

[28] S. C. Sinha, B. N. Chaudhari, J. W. Burger, G. Yakovleva, J. V. Davisson, J. L. Smith, J. Biol. Chem. 2004, 279, 15491.

[29] H. J. Müllenmeister, rohstoff-spiegel.de 2009, $19,9$. 